\title{
Retrospective analysis of the impact of sternum closure technique on postoperative comfort and rehabilitation
}

\author{
Leszek Kukulski, Aleksandra Krawczyk, Jerzy Pacholewicz \\ Department of Cardiac, Vascular and Endovascular Surgery and Transplantology in Zabrze, \\ Medical University of Silesia in Katowice, Silesian Center for Heart Diseases, Poland
}

Kardiochirurgia i Torakochirurgia Polska 2018; 15 (4): 233-237

\begin{abstract}
Introduction: Sternum closure techniques have been compared regarding biomechanics, efficacy in high-risk patients and prevention of mediastinitis or sternal dehiscence. There are no papers concerning patients' comfort and postoperative rehabilitation rate.

Aim: To establish the best surgical closure technique after midline sternotomy regarding the lowest pain level in the postoperative period and the highest rate of postoperative rehabilitation.

Material and methods: A retrospective analysis was performed on a group of 100 patients after cardiothoracic procedures which was divided into 3 subgroups according to sternal closure technique based on postoperative thoracic X-ray. To assess patients' pain and their physical activity we used a custom questionnaire. The statistical analysis was performed on the data regarding occurrence of wound healing complications risk factors, Numerical Rating Scale (NRS) for Pain score, the number of days until achieving important rehabilitations stages and the occurrence of sternal refixation.

Results: Subgroups had 35, 33 and 32 patients. The statistical analysis showed significantly lower NRS scores between the $14^{\text {th }}(p=0.0012)(1.17)$ and $30^{\text {th }}(p=0.0196)$ day $(0.65)$ after the procedure in the group sutured with only single interrupted wire. There was also a significant difference in the number of days between the operation and the first time the patient could lie sideways ( $p=0.0105$ ). There was no statistically significant difference between the three groups regarding other measured factors.

Conclusions: The single wire suture provides less pain at the $14^{\text {th }}$ and $30^{\text {th }}$ day postoperatively measured on the NRS and ensures faster rehabilitation compared to sternal closing technique which involves placing both single and figure-of-8 sutures.
\end{abstract}

Key words: median sternotomy technique, rehabilitation, pain, cardiothoracic.

\section{Streszczenie}

Wprowadzenie: Techniki zespolenia mostka po sternotomii pośrodkowej były porównywane pod względem biomechaniki zespolenia, zapobiegania powikłaniom gojenia się rany, profilaktyki rozejścia się mostka i zapalenia śródpiersia lub przydatności u pacjentów wysokiego ryzyka. Nie ma jednak publikacji dotyczących oceny komfortu pacjenta i postępu rehabilitacji pooperacyjnej.

Cel: Określenie najkorzystniejszej techniki szycia mostka pod względem dolegliwości bólowych oraz komfortu rehabilitacji pooperacyjnej.

Materiat i metody: Retrospektywnej analizie poddano grupę 100 chorych po zabiegach kardiochirurgicznych, którą podzielono na 3 podgrupy w zależności od zastosowanej techniki zespolenia mostka na podstawie pooperacyjnych zdjęć RTG. Do analizy dolegliwości bólowych i aktywności fizycznej zastosowano autorski kwestionariusz. Analizie statystycznej poddano czynniki ryzyka wystąpienia powikłań gojenia się rany, ocenę bólu po zabiegu w skali NRS, liczbę dni od zabiegu do osiągnięcia ważnych etapów rehabilitacji oraz częstość występowania powikłań.

Wyniki: Podgrupy liczyły 35, 33 i 32 pacjentów. Analiza wykazała istotnie mniejsze dolegliwości w skali NRS w $14 .(p=0,0012)$ i 30. $(p=0,0196)$ dobie po zabiegu w grupie pacjentów, u których zastosowano tylko szwy pojedyncze, średnio 1,17 pkt i 0,65 pkt. Również w tej grupie pacjentów stwierdzono istotnie krótszy czas od zabiegu do możliwości ułożenia się na boku ( $p=$ 0,0105). Nie wykazano istotnych statystycznie różnic pomiędzy grupami w zakresie pozostałych badanych parametrów.

Wnioski: Technika zespolenia mostka polegająca na założeniu jedynie szwów pojedynczych umożliwia uzyskanie mniejszych dolegliwości bólowych w 14. i 30. dobie pooperacyjnej ocenianych w skali NRS oraz szybszą rehabilitację pooperacyjną, co poprawia komfort życia pacjentów, w porównaniu z technikami polegającymi na założeniu jednocześnie szwów pojedynczych i w kształcie ósemek.

Słowa kluczowe: sternotomia pośrodkowa, rehabilitacja, ból, kardiochirurgia.

Address for correspondence: Leszek Kukulski, Silesian Center for Heart Diseases, 9 M. Curie-Skłodowskiej St, 41-800 Zabrze, Poland, phone: +48 663780 545, e-mail: leszekkukulski@gmail.com

Received: 6.08.2018, accepted: 7.10.2018. 


\section{Introduction}

Midline sternotomy as an operating access technique was first introduced by Julian et al. in 1957. Since then it has been widely used in a range of cardiothoracic procedures, as it provides an excellent access to the heart and the great vessels [1]. Initially the technique of peristernal single wire suture was established as the best way to close the sternum. However, Murray et al. proposed a new technique of sternum closure, using figure-of- 8 wire suturing [2], which was reported to be very effective in patients with greater risk of wound healing complications, such as patients with obesity, diabetes or chronic obstructive pulmonary disease [3]. This technique requires placing sutures in the shape of a figure of 8 . There are many studies comparing closing techniques regarding biomechanics [4-8], efficacy in highrisk patients [9] and complication rates including sternal dehiscence or mediastinitis [10, 11]. Losanoff et al. compared biomechanical properties of 6 sternal closures on 53 human cadaver models. They concluded that the mechanical stability of a single wire closure is significantly greater than that of figure-of-8 closures [5]. Schimmer et al. performed a prospective randomized clinical trial on group of 339 patients, which included a subgroup of elderly patients (over 75 years) with higher risk of wound healing complications. The trial showed no statistically significant difference between the assessed closure techniques [9]. Surprisingly, there is a lack of research regarding patients' postoperative comfort, pain and rehabilitation rate in relation to the surgical closure technique after median sternotomy. One established method of determining the level of patients' pain is the Numeric Rating Scale for Pain (NRS) [12]. It is a scale with 11 levels, where 0 means no pain and

Table I. Clinical characteristics of patients

\begin{tabular}{lc} 
Parameter & Value \\
Number of patients & 100 \\
\hline Age & $66.66 \pm 9.74$ \\
\hline Gender: & $74(74 \%)$ \\
\hline Male & $26(26 \%)$ \\
\hline Female & $30(30 \%)$ \\
\hline Diabetes & $33(33 \%)$ \\
\hline Obesity & $79(79 \%)$ \\
\hline IMA harvest & $7(7 \%)$ \\
\hline Chronic kidney disease & 47 \\
\hline Type of procedure: & 25 \\
\hline CABG & 13 \\
\hline OPCAB & 7 \\
\hline CABG + AVR & $8(2 \%)$ \\
\hline AVR & \\
\hline Other & \\
\hline Sternal refixation & \\
\hline
\end{tabular}

IMA - internal mammary artery, CABG - coronary artery bypass surgery, OPCAB - off-pump coronary artery bypass, AVR - aortic valve replacement
10 extreme pain, also described as the strongest pain the patient can imagine.

\section{Aim}

The aim of the study was to evaluate and establish the best surgical closure technique after midline sternotomy regarding the lowest pain level in the postoperative period and the highest rate of postoperative physical rehabilitation.

\section{Material and methods}

A retrospective analysis was performed on a group of 100 patients (74 men and 26 women, at mean age of 66.66 \pm 9.74 years) after on-pump and off-pump cardiothoracic procedures completed with midline sternotomy. Clinical characteristics of the whole analyzed group are presented in Table I. To assess pain severity and physical activity of patients we used a questionnaire which was specially developed based on the available literature and our clinical experience [13-17]. It contains 16 questions divided into three groups. The first group of questions concerns the patient's pain in the postoperative period, the second one the physical rehabilitation rate and the third one is related to the complications in wound healing. The data for the questionnaire were obtained by direct interview with the patient at the rehabilitation department or telephone interview carried out at least 30 days after the surgical procedure. The analyzed group was divided into 3 subgroups according to the sternal closure technique which was used during the cardiothoracic operation: group 1 - single interrupted wire; group 2 - figure-of- 8 wire; group 3 - single interrupted wire and figure-of- 8 wire. The type of closure technique was determined based on the postoperative thoracic $X$-ray.

\section{Statistical analysis}

The statistical analysis was performed on the data containing information about the occurrence of wound healing complication risk factors (age, sex, diabetes, obesity, chronic kidney disease, left internal mammary artery (LIMA) and right internal mammary artery (RIMA) harvest or just LIMA harvest), NRS for Pain score, the number of days until achieving important rehabilitations stages (Kruskal-Wallis test), the number of "yes" answers in certain questions and finally the need for sternal refixation ( $\chi^{2}$ Pearson test). The software used for statistical analysis was Statistica 13 (produced by StatSoft).

\section{Results}

Groups 1, 2 and 3 had 35, 33 and 32 patients respectively. The characteristics of these groups are shown in Table II. The most frequent wound healing complication risk factors were diabetes and obesity. Statistical analysis showed significant differences in NRS scores between the $14^{\text {th }}$ $(p=0.0012)$ and $30^{\text {th }}(p=0.0196)$ days after the procedure. The lowest mean NRS score at 14 and 30 days after the operation was observed in group 1 - single interrupted wires, 
Table II. Subgroups' characteristics

\begin{tabular}{|c|c|c|c|c|}
\hline Parameter & $\begin{array}{l}\text { Single suture } \\
\text { Group } 1\end{array}$ & $\begin{array}{l}\text { Figure-of-8 suture } \\
\text { Group } 2\end{array}$ & $\begin{array}{l}\text { Single and figure-of-8 suture } \\
\text { Group } 3\end{array}$ & $P$-value \\
\hline Number of patients & 35 & 33 & 32 & \\
\hline Age & $65.14 \pm 10.55$ & $64.67 \pm 9.05$ & $67.25 \pm 9.60$ & 0.4341 \\
\hline Gender: & & & & 0.1588 \\
\hline Male & 29 (82.8\%) & $25(75.8 \%)$ & $20(62.5 \%)$ & \\
\hline Female & $6(17.2 \%)$ & $8(24.2 \%)$ & $12(37.5 \%)$ & \\
\hline Diabetes & 11 (31\%) & $8(24 \%)$ & $11(34 \%)$ & 0.6189 \\
\hline Inadequate body weight: & $14(40 \%)$ & $9(27 \%)$ & $10(31 \%)$ & 0.5196 \\
\hline Overweight & 5 & 3 & 4 & \\
\hline Obesity 1 degree & 7 & 5 & 3 & \\
\hline Obesity 2 degree & 2 & 1 & 3 & \\
\hline LIMA harvest & 31 (88.57\%) & $27(81.82 \%)$ & $21(65.63 \%)$ & 0.06262 \\
\hline LIMA + RIMA harvest & $1(2.86 \%)$ & $4(12.12 \%)$ & $3(9.38 \%)$ & 0.30365 \\
\hline Chronic kidney disease & $2(6 \%)$ & $2(6 \%)$ & $4(12 \%)$ & 0.2775 \\
\hline Procedure type: & & & & 0.1388 \\
\hline$\overline{C A B G}$ & 23 & 13 & 11 & \\
\hline OPCAB & 4 & 11 & 10 & \\
\hline$\overline{C A B G}+\mathrm{AVR}$ & 6 & 3 & 4 & \\
\hline$\overline{A V R}$ & 1 & 3 & 3 & \\
\hline Other & 1 & 3 & 4 & \\
\hline Sternal refixation & $1(2.85 \%)$ & $0(0 \%)$ & $1(3.12 \%)$ & 0.6031 \\
\hline Number of sutures, mean & $8 \pm 0.94$ & $5 \pm 0.79$ & $5.56 \pm 1.19$ & $<0.001$ \\
\hline
\end{tabular}

$1.17 \pm 1.77$ points and $0.65 \pm 1.28$ points respectively. A significantly higher score on the NRS was observed in group 3 - single and figure-of- 8 wire, $3.16 \pm 2.54$ points at 14 days and $1.71 \pm 2.13$ at 30 days after the procedure. These results are shown in Figure 1. There was also a significant difference in number of days between the operation and the first time the patient could lie sideways ( $p=0.0105)$. The mean number of days until achieving this stage of rehabilitation was the lowest in group 1 (30.54 \pm 23.45 days) and was significantly higher in group 3 (49.71 \pm 22.74 days). These results are shown in Figure 2. Moreover, the mean number of sutures applied during surgical sternal closure was the highest in group 1 . There was no statistically significant difference between the three groups regarding a feeling of sternal instability, painkiller medication need, pain during coughing and number of days needed for achieving other stages of rehabilitation. The frequency of sternal refixation was also similar in all the groups. The detailed results of the questionnaire are presented in Table III.

\section{Discussion}

A median sternotomy in patients with wound healing risk factors is associated with high rates of postoperative complications. Sternum stability, postoperative comfort and lack of pain are very important factors to achieve a proper level of postoperative rehabilitation. Although there are some papers which include biomechanical comparison of these techniques, there are no previously published studies

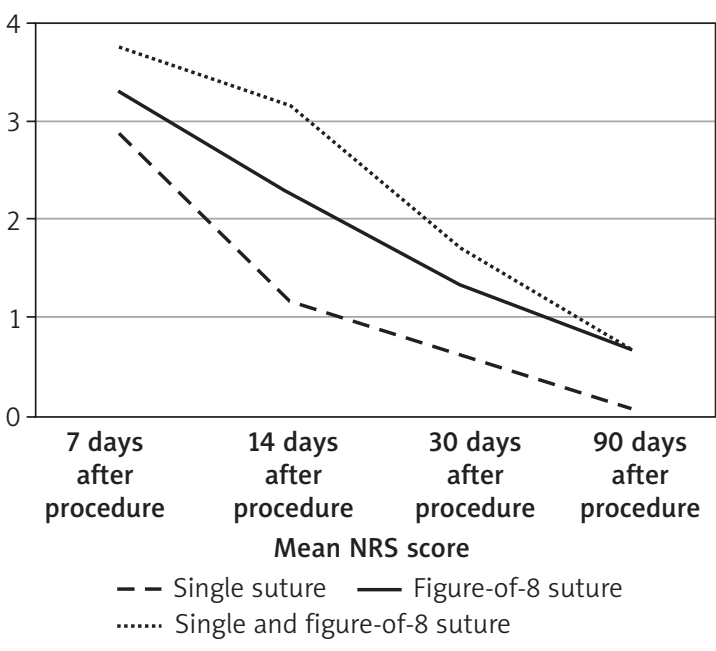

Fig. 1. Mean NRS of Pain score at 7, 14, 30 and 90 days after procedure

comparing sternum closure techniques regarding patients' postoperative comfort and pain. Krejca et al. created 60 bovine sternum models, which were used to perform stress tests. It was established that single wire sutures provide better fixation stability compared to figure-of-8 sutures [4]. Additionally, Losanoff et al. noted a similar advantage of single wire technique over figure-of- 8 sutures and 3 other closure techniques, but in this case specially made measuring equipment and 53 human cadaveric sterna were used [5]. These findings are consistent with our results, because 


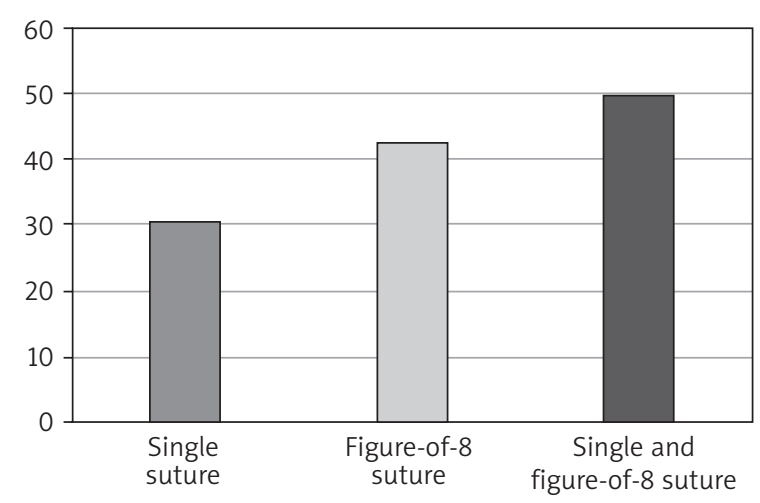

Fig. 2. Mean number of days between procedure and first time the patient could lie sideways

fixation stability is stated as an important factor improving fast bone healing [18], which is a key factor of effective rehabilitation, which was proven, to some extent, to be better in patients closed with single wire sutures. The problem that needs to be refined is the use of single sutures in patients with osteoporotic sternum, where the possibility of cutting through the edges with metal wires is probable. In this case, the use of figure-of-8 sutures to close the sternum may contribute to greater stability and healing of the postoperative wound.

In our study, sternal refixation was needed in 2/100 patients (2\%). Heilmann et al. [19] noted in their registry 19 cases of similar complications, which is $1.46 \%$ of the entire group $(n=1297)$. The higher rate of sternal refixation could be explained by a higher rate of one of the main wound healing complication risk factors - diabetes, which was $30 \%$ in our study and $24 \%$ in Heimann's registry.

It is worth highlighting that the single wire technique was better in terms of subjective pain sensation at 14 and 30 postoperative day despite a statistically higher number of sutures and subsequently more severe trauma to the chest wall, which is known to be one of the causes of postoperative pain [20].

The limitations of the study are the retrospective analysis and the limited number of patients. However, the study's results reflect fully the risk of complications, including pre-operative risk factors in daily clinical practice.

Taking into consideration the fact that the quality of life and patients' comfort are becoming increasingly important and that there are no previous prospective and randomized trials, it would be worth designing and conducting such a study. It would also be valuable to use more standardized and validated methods such as a sternal instability scale [21] or a quality of life scale [22] and include new sternal closing methods, e.g. using reinforced steel wires [23], titanium hooks [24] or ultra-high-molecular-weight polyethylene sutures [25]. Collecting more data on beneficial effects in terms of patient comfort and pain of certain sternal closing techniques could help in changing surgeons' operative approach or even task force recommendations and subsequently improve patients' well-being and speed up postoperative rehabilitation.

Table III. Detailed results of questionnaire

\begin{tabular}{|c|c|c|c|c|}
\hline Question & $\begin{array}{l}\text { Single suture } \\
\text { Group } 1\end{array}$ & $\begin{array}{l}\text { Figure-of-8 suture } \\
\text { Group } 2\end{array}$ & $\begin{array}{l}\text { Single and figure-of- } 8 \text { suture } \\
\text { Group } 3\end{array}$ & $P$-value \\
\hline Sternal instability sensation & $4(11.43 \%)$ & $5(15.15 \%)$ & $2(6.25 \%)$ & 0.5156 \\
\hline $\begin{array}{l}\text { Additional pain medication during } \\
\text { hospitalization }\end{array}$ & $10(28.57 \%)$ & $12(36.36 \%)$ & $10(31.25 \%)$ & 0.7842 \\
\hline Coughing-related pain 30 days after procedure & $26(76.47 \%)$ & $18(54.55 \%)$ & $19(61.29 \%)$ & 0.1585 \\
\hline Coughing-related pain 90 days after procedure & $3(18.75 \%)$ & $4(33.33 \%)$ & $6(50.00 \%)$ & 0.2168 \\
\hline $\begin{array}{l}\text { Additional pain medication } 7 \text { days after } \\
\text { procedure hospitalization }\end{array}$ & $14(40.00 \%)$ & $11(33.33 \%)$ & $10(31.25 \%)$ & 0.7325 \\
\hline $\begin{array}{l}\text { Increased sternal-related pain limiting } \\
\text { everyday activities }\end{array}$ & $8(23.53 \%)$ & $11(33.33 \%)$ & $14(43.75 \%)$ & 0.2195 \\
\hline Sleep-depriving pain & $9(25.71 \%)$ & $16(48.48 \%)$ & $11(34.38 \%)$ & 0.1440 \\
\hline Sternal refixation & $1(2.85 \%)$ & $0(0 \%)$ & $1(3.12 \%)$ & 0.60311 \\
\hline Wound healing complications & $3(8.57 \%)$ & $3(9.09 \%)$ & $5(15.63 \%)$ & 0.5966 \\
\hline Mean NRS score 7 days after procedure & $2.86 \pm 2.43$ & $3.29 \pm 2.64$ & $3.75 \pm 2.59$ & 0.3601 \\
\hline Mean NRS score 14 days after procedure & $1.17 \pm 1.77$ & $2.26 \pm 1.96$ & $3.16 \pm 2.54$ & 0.0012 \\
\hline Mean NRS score 30 days after procedure & $0.65 \pm 1.28$ & $1.33 \pm 1.51$ & $1.71 \pm 2.13$ & 0.0196 \\
\hline Mean NRS score 90 days after procedure & $0.07 \pm 0.26$ & $0.67 \pm 1.11$ & $0.67 \pm 1.5$ & 0.1788 \\
\hline $\begin{array}{l}\text { Mean number of days between procedure and } \\
\text { ability to lie sideways }\end{array}$ & $30.54 \pm 23.45$ & $42.50 \pm 30.49$ & $49.71 \pm 22.74$ & 0.0105 \\
\hline $\begin{array}{l}\text { Mean number of days between procedure and } \\
\text { ability to stand up without any extra support }\end{array}$ & $20.26 \pm 16.03$ & $28.33 \pm 26.41$ & $23.00 \pm 15.03$ & 0.3661 \\
\hline $\begin{array}{l}\text { Mean number of days between procedure and } \\
\text { ability to load shoulder ring }\end{array}$ & $53 \pm 27.64$ & $58.09 \pm 37.55$ & $51.21 \pm 22.01$ & 0.9828 \\
\hline
\end{tabular}




\section{Conclusions}

The single wire suture provides less pain at the $14^{\text {th }}$ and $30^{\text {th }}$ day postoperatively measured using the NRS compared to the sternal closing technique which involves placing both single and figure-of- 8 sutures. The single wire suture ensures a faster rehabilitation process, thus improving patients' quality of life compared to the sternal closing technique, which involves placing both single and figure-of-8 sutures.

\section{Disclosure}

The authors report no conflict of interest.

\section{References}

1. Julian OC, Lopez-Belio M, Dye WS, Javid H, Grove WJ. The median sternal incision in intracardiac surgery with extracorporeal circulation: a general evaluation of its use in heart surgery. Surgery 1957; 42: 753-761.

2. Murray KD, Pasque MK. Routine sternal closure using six overlapping figureof-8 wires. Ann Thorac Surg 1997; 64: 1852-1854.

3. Tavilla G, van Son JA, Verhagen AF, Lacquet LK. Modified Robicsek technique for complicated sternal closure. Ann Thorac Surg 1991; 52: 1179-1180.

4. Krejca M, Szmagała P, Skarysz J, Bochenek K, Ulczok R, Bis J, Bochenek A. Force distribution in wire sternum sutures: the consequences for sternal closure rigidity. Med Sci Monit 2003; 9: BR134-44.

5. Losanoff JE, Collier AD, Wagner-Mann CC, Richman BW, Huff H, Hsieh Fh, Diaz-Arias A, Jones JW. Biomechanical comparison of median sternotomy closures. Ann Thorac Surg 2004; 77: 203-209.

6. McGregor WE, Trumble DR, Magovern JA, Robicsek F. Mechanical analysis of midline sternotomy wound closure. J Thorac Cardiovasc Surg 1999; 117: 1144-1150.

7. Casha AR, Yang L, Kay PH, Saleh M, Cooper GJ. A biomechanical study of median sternotomy closure techniques. Eur J Cardiothoracic Surg 1999; 15 : 365-369.

8. Casha AR, Gauci M, Yang L, Saleh M, Kay PH, Cooper GJ. Fatigue testing median sternotomy closures q. Eur J Cardiothoracic Surg 2001; 19: 249-253.

9. Schimmer C, Sommer SP, Bensch M, Bohrer T, Aleksic I, Leyh R. Sternal closure techniques and postoperative sternal wound complications in elderly patients. Eur J Cardiothoracic Surg 2008; 34: 132-138.

10. Ramzisham ARM, Raflis AR, Khairulasri MG, Min JOS, Fikri AM, Zamrin MD. Figure-of-eight vs. interrupted sternal wire closure of median sternotomy. Asian Cardiovasc Thorac Ann 2009; 17: 587-591.
11. Schimmer C, Reents W, Berneder S, Eigel P, Sezer O, Scheld H, Sahraoui K, Gansera B, Deppert O, Rubio A, Feyrer R, Sauer C, Elert O, Leyh R. Prevention of sternal dehiscence and infection in high-risk patients: a prospective randomized multicenter trial. Ann Thorac Surg 2008; 86: 1897-1904.

12. Hawker GA, Mian S, Kendzerska T, French M. Measures of adult pain: Visual Analog Scale for Pain (VAS Pain), Numeric Rating Scale for Pain (NRS Pain), McGill Pain Questionnaire (MPQ), Short-Form McGill Pain Questionnaire (SFMPQ), Chronic Pain Grade Scale (CPGS), Short Form-36 Bodily Pain Scale (SF. Arthritis Care Res 2011; 63 (S11): S240-S252.

13. Cahalin PL, LaPier Kinney T, Shaw KD. Sternal precautions: is it time for change? Precautions versus restrictions - a review of literature and recommendations for revision. Cardiopulm Phys Ther J 2011; 22: 5-15.

14. Eisenberg E, Pultorak Y, Pud D, Bar-El Y. Prevalence and characteristics of post coronary artery bypass graft surgery pain (PCP). Pain 2001; 92: 11-17.

15. Tucker B, Jenkins S, Davies K, McGann R, Waddell J, King R, Kirby V, Lloyd C. The physiotherapy management of patients undergoing coronary artery surgery: a questionnaire survey. Aust J Physiother 1996; 42: 129-137.

16. Careaga Reyna G, Aguirre Baca GG, Medina Concebida LE, Borrayo Sanchez G, Prado Villegas G, Arguero Sanchez R. Risk factors for mediastinitis and sternal dehiscence after cardiac surgery. Rev Esp Cardiol 2006; 59: 130-135.

17. Lahtinen P, Kokki H, Hynynen M. Pain after cardiac surgery. Anesthesiology 2006; 105: 794-800.

18. Sargent LA, Seyfer AE, Hollinger J, Hinson RM, Graeber GM. The healing sternum: a comparison of osseous healing with wire versus rigid fixation. Ann Thorac Surg 1991; 52: 490-494.

19. Heilmann C, Stahl R, Schneider C, Sukhodolya T, Siepe M, Olschewski M, Beyersdorf F. Wound complications after median sternotomy: a single-centre study. Interact Cardiovasc Thorac Surg 2013; 16: 643-648.

20. Moore R, Follette DM, Berkoff HA. Poststernotomy fractures and pain management in open cardiac surgery. Chest 1994; 106: 1339-1342.

21. El-ansary D, Adams R, Toms L, Elkins M. Sternal instability following coronary artery bypass grafting. Theory Pract 2000; 16: 27-33.

22. Burckhardt CS, Anderson KL. The Quality of Life Scale (QOLS): reliability, validity, and utilization. Health Qual Life Outcomes 2003; 1: 60.

23. McGregor WE, Payne M, Trumble DR, Farkas KM, Magovern JA. Improvement of sternal closure stability with reinforced steel wires. Ann Thorac Surg 2003; 76: 1631-1634.

24. Kilian E, Mair H, Reichart B, Lamm P. Sternal closure after median sternotomy: a new technique using titanium hooks and wires applied parasternally. Interact Cardiovasc Thorac Surg 2013; 16: 721-723.

25. Ando T, Akiyama D, Okada H, Furukawa H, Takeda M. Novel sternum closure technique using ultra high molecular weight polyethylene sutures. Kyobu Geka 2016; 69: 1055-1058. 